\title{
Production and trade analysis in the Iberian cork sector: economic characterization of a forest industry
}

\author{
*Jorge Sierra-Pérez ${ }^{1,2}$, Jesús Boschmonart-Rives ${ }^{1,3}$, Xavier Gabarrell ${ }^{1,4}$ \\ 1 Sostenipra (ICTA - IRTA - Inèdit Innovació SL) 2014 SGR 1412. Institute of Environmental \\ Science and Technology (ICTA), Universitat Autònoma de Barcelona (UAB), 08193 - \\ Cerdanyola del Vallès (Bellaterra), Barcelona, Spain. \\ 2 Centro Universitario de la Defensa. Ctra. de Huesca s/n, 50.090, Zaragoza, Spain \\ 3 Inèdit Innovació, S.L. Parc de Recerca de la Universitat Autònoma de Barcelona (UAB), \\ 08193 - Cerdanyola del Vallès (Bellaterra), Barcelona, Spain \\ 4 Department of Chemical Engineering (XBR), Universitat Autònoma de Barcelona (UAB), \\ 08193 - Cerdanyola del Vallès (Bellaterra), Barcelona, Spain \\ * Corresponding Author: \\ Phone: + 34976739836 . \\ Fax: +34976739824 \\ E-mail: jsierra@unizar.es
}

\begin{abstract}
Cork oak forest grows endemically in the coastal regions of the western Mediterranean basin, particularly in the Iberian Peninsula. The cork agro-forestry systems play a key role in ecological processes, and the outer bark, or cork, can be extracted sustainability without damaging the tree or affecting biodiversity. Because of the properties of the cork, an important forestry and industrial structure has been developed around its most valuable goods. This paper describes the current global trade patterns in the Iberian Peninsula, where Portugal and Spain are world leaders. Although these countries bring most of their cork trade flows together with the rest of the world, there are clear differences between these sectors. The aim of this study was to identify these differences and to characterize each analysed sector from an economic perspective. The primary difference between the sectors lies in the characteristics of their supply chain and their capacity to generate wealth from raw cork. Portugal primarily produces and processes raw cork into products with high added value. Spain bases its cork sector on raw material and half-manufactured cork, and it is not able to use the full potential that cork provides. Catalonia is an exception because it is the global leader in the champagne stopper market. To encourage the development of the entire cork sector, every link in the supply chain should be strengthened through the establishment of companies and the generation of employment, and therefore the development of rural areas. Moreover, this industry must establish its own development strategies for the future, thereby increasing its investment in R\&D and innovation in relation to the opportunities identified as follows: the potential for diversification beyond the wine market, the improvement potential for forest management and the enhancement of sustainability and eco-efficiency in every link of the cork supply chain.
\end{abstract}

\section{Keywords}

Cork industry; international trade; Iberian Peninsula; cork supply chain; natural resource economics; Research and development, sustainability 


\section{Introduction}

Cork oak (Quercus suber) forests are one of the best examples of balanced conservation and development in the world. They play a key role in ecological processes such as water retention, soil conservation, and carbon storage (Rives et al., 2013b). The cork oak tree is a long-lived species (250-350 years) with an outer bark, or cork, which is characterized by its elasticity, impermeability and good thermal insulation (Pereira, 2007). Cork extraction is a sustainable process because it does not damage the tree, and following extraction, new bark regrows. This process occurs every 9-14 years, depending on the area, until the tree is approximately 200 years old (Pereira and Tomé, 2004). The cork oak forests are distributed along the coastal regions of the western Mediterranean basin, including Algeria, France, Italy, Morocco, Portugal, Spain, Tunisia, the islands of Corsica, Sardinia and Sicily (Figure 1). The most extensive forests are concentrated in the Iberian Peninsula, which is located in southern Europe. Portugal and Spain make up $34 \%$ and $27 \%$ of the world's cork oak forests, respectively (Table 1).

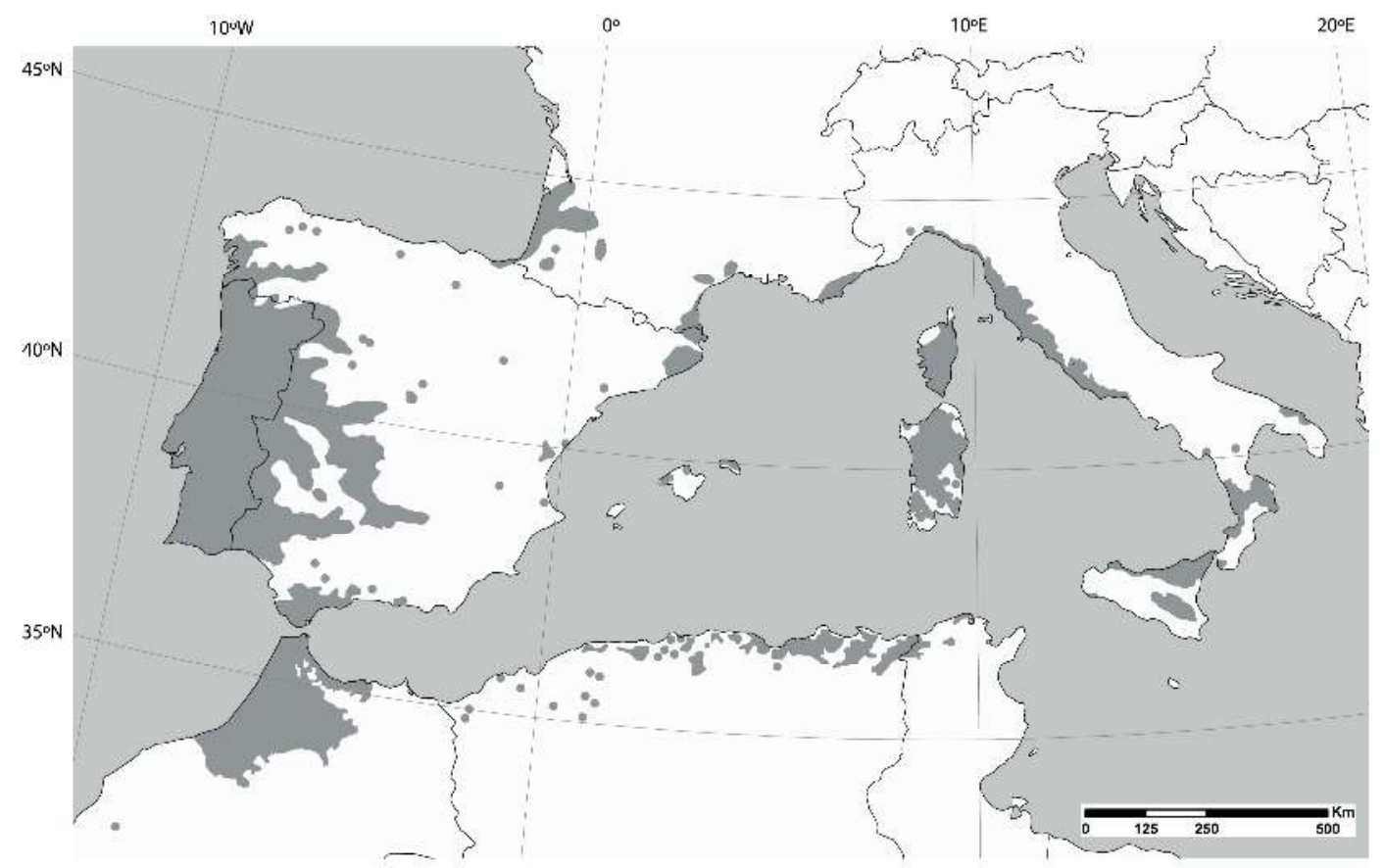

Figure 1. Distribution map of cork oak (Quercus suber). EUFORGEN 2009. www.euforgen.org

Cork oak represents a good example of an agroforestry system, i.e., an intensive land management system in which trees and/or shrubs are deliberately combined with crops and/or livestock on the same land. The purpose of an agroforestry system is to optimize the benefits of biological interactions (Garrett and Buck, 1997). Cork production is the most important source of revenue in cork oak agroforestry (Borges, 1997), and it is considered the key element for preserving these systems (Campos et al, 2008b). The Iberian Peninsula has the highest rate of cork extraction worldwide, at more than $80 \%$ (Table 1). In The Magreb (Morocco, Algeria and Tunisia), there is a notable area of cork oak forest with great potential for growth. Iberian cork oak forests are currently underexploited because in both Portugal and Spain, approximately $90 \%$ of the cork oak forests are privately owned. This private ownership can lead to a near total lack of natural and artificial regeneration of cork oak because of the high investment needed for very long-term benefits (Zapata, 2002). This problem has been partly resolved by public subsidies, which, as discussed below, promote forestry and the economic development of cork regions.

Increasing the level of exploitation is crucial for appropriate forest management. On the one hand, control and enhance the natural regeneration of cork. That is, supporting the complex 
processes that occur from the time a seed is produced to the time its offspring reaches maturity. On the other hand, when managing natural regeneration is not sufficient, it is necessary to introduce artificial regeneration through the application of forestry activities (Aronson et al., 2009). Artificial regeneration is relatively recent, but it has greatly increased as a consequence of the afforestation programs in the Common Agriculture Policy (EU 2080/92) (Pereira and Tomé, 2004). The primary forestry activities are the manual clearing of bushes, pruning, plant protection treatments and removing rocks. The ultimate objective of these activities is to create optimal conditions for performing the extraction and transport of cork, in addition to ensuring the good health of cork, which partly determines the best or worst qualities of the cork harvest (Campos et al., 2008a). Moreover, these forestry activities can be beneficial for the sustainable development of the forestry industry and the rational use of raw materials and other potential forestry products. Some of these potential products are associated with both traditional agrosilvopastoral practices and the gathering of a number of non-timber products (e.g., mushrooms, berries, aromatic plants and hunting) (Bojnec and Fertö 2014, Campos et al. 2008b, Zapata 2002). Within this context, public institutions have increased concerns about natural areas and rural employment, and they have responded by granting subsidies for cork oak reforestation and its corresponding increase in cork production (Campos et al. 2008a, EU 2006, EU 1996).

Table 1: Worldwide cork oak area and raw cork production by country (APCOR, 2014)

\begin{tabular}{ccc|cc}
\hline Country & $\begin{array}{c}\text { Cork oak area } \\
\text { (ha) }\end{array}$ & $\begin{array}{c}\text { Cork oak area } \\
(\%)\end{array}$ & $\begin{array}{c}\text { Raw cork } \\
\text { extracted } \\
\text { yearly (t) }\end{array}$ & $\begin{array}{c}\text { Raw cork } \\
\text { extracted } \\
\text { yearly (\%) }\end{array}$ \\
\hline Portugal & 715,922 & 34 & 100,000 & 49.6 \\
Spain & 574,248 & 27 & 61,504 & 30.5 \\
Morocco & 383,120 & 18 & 11,686 & 5.8 \\
Algeria & 230,000 & 11 & 9,915 & 4.9 \\
Tunisia & 85,771 & 4 & 6,962 & 3.5 \\
France & 65,228 & 3 & 5,200 & 2.6 \\
Italy & 64,800 & 3 & 6,161 & 3.1 \\
\hline Worldwide & $\mathbf{2 , 1 1 9 , 0 8 9}$ & $\mathbf{1 0 0}$ & $\mathbf{2 0 1 , 4 2 8}$ & $\mathbf{1 0 0}$ \\
\hline
\end{tabular}

The Iberian Peninsula has had concentrated cork production, industry and commerce since the mid- $20^{\text {th }}$ century because of its the location in the major wine-growing regions of the world, the presence of abundant raw cork and a cheap workforce (OIV 2013, Parejo 2010, Zapata et al. 2009, Parejo 2004, Zapata 2002). This combination of factors has resulted in a concentration of the global cork business in both Portugal and Spain, but in an unequal distribution. Portugal has experienced an important evolution; it has become the world's primary cork industry power and replaced Spain from the preeminent position that it had occupied since the 18th century. In recent years, the cork sector has also suffered from the European debt crisis, primarily because of the decrease in wine consumption worldwide (OIV, 2013), and there has therefore been a decrease in cork stopper sales. According to information from the Portuguese Ministry of Solidarity and Social Security, the number of companies in the cork industry decreased by 18 percent from 2007 to 2011, but it has experienced significant growth in recent years (APCOR, 2014). According to the Spanish Ministry of Industry, Energy and Tourism, industrial production in the cork sector has decreased by $24 \%$ since 2005 (INE, 2013). 
The Iberian cork sector has generated an important forestry and industrial structure around this raw material. The companies and organizations that compose this structure are part of the supply chain for the sector, which consists of a network of organizations or links that are involved in different processes and activities through upstream and downstream linkages that produce value in the form of products and services for the ultimate consumer (Christopher, 1998). In the case of the cork industry, these links encompass the extraction of raw materials to the finished product. The present study is focused on the links that provide greater value to the product, that is, the forestry, the half-manufactured cork industry and the cork-processing industry, and it excludes the storage, distribution and retail processes. The differences between these links are significant because the nature of the activities is different, involving either forestry or industry. Moreover, each link adds a different value to the final product, and the wealth generated by the activities is different in each case. The primary stage, namely the forestry link, has significant implications related to forest management in terms of the quantity and quality of cork, as noted above. These implications affect the rest of the supply chain because the uniform supply of raw material flows is essential for the sustainable development of the successive links. Some studies have proposed different types of controls to regulate and optimize cork harvest scheduling, to avoid flow constraints (Costa et al., 2010). A better quality of raw cork can provide better selling opportunities and higher prices, and thereby increase the profitability of cork farms. The next link in the supply chain is the half-manufactured cork industry. After extracting the cork and allowing its subsequent stabilisation in the forest, this material is transported to a preparation factory, where the slabs are boiled and selected to manufacture natural cork stoppers or agglomerated cork products (Rives et al., 2011). This industry is located in the proximity of cork oak forests and is made up of small companies with low technological development. However, because of the economic crisis, the cost of the raw material has increased and its supply is very fragmented; large manufacturing companies are beginning to integrate the half-manufacturing activities into their cork-processing industries (Zapata, 2002). The cork-processing industry is the link in the supply chain in which there is more value added to the material. This industry is primarily made up of manufacturers of wine and champagne stoppers and agglomerated products, e.g., thermal insulation panels. In addition to adding economic value to the processed raw material, these manufacturers develop the supply chain with strong linkages for intermediate use, which are capable of processing the raw cork and half-manufactured cork (Bojnec and Fertö, 2014). To characterize an industrial supply chain, we have to analyse each link by identifying their strengths and weaknesses.

The purpose of this paper is to analyse the global trade of the cork industry in the Iberian Peninsula by using an economic approach and mapping the current trade patterns, specifically for the most valuable goods, that is, raw cork from the forest, natural and champagne cork stoppers and agglomerated cork. Through this empirical analysis, a characterization of the cork industry in the Iberian Peninsula has been made to identify the differences between the analysed sectors.

\section{Material and methods}

\subsection{System definition}

The system considered in this study is the cork industry in the Iberian Peninsula, and the time period analysed is for one year, namely 2012. The study is divided into three levels; with a global level, as in the Iberian Peninsula; a country level, specifically Portugal and Spain; and a regional level, that is, Catalonia. The Portuguese and Spanish cork sectors are analysed because of their leadership positions in the global cork market, as discussed above. The Catalan sector, despite being included in Spanish data, has been selected because of its specific and interesting characteristics with respect to the rest of the Spanish cork industry. Catalonia has a Cluster of interrelated companies in the cork sector that collaborate strategically for common benefits. This Cluster gathers all stakeholders in the supply chain, from both end 
product manufacturers and half-manufacturing companies, with production managers and final product marketers (Megía and Martín, 2009). Moreover, Catalonia is a landmark in the cork field because it is where the stopper business began.

\subsection{Data}

Trade flow data are presented for the following three levels: the Iberian Peninsula, Portugal and Spain, and Catalonia. The products are categorized by the Harmonized Commodity Description and Coding System ${ }^{1}$ (or HS), which is used for classifying goods. Cork and its manufacturers belong to the $45^{\text {th }}$ group, in which four subgroups are defined by the six-digit code classification shown in Table 2. The prevalence of the subgroup related to natural cork (450110), natural cork stoppers (450310) and agglomerated cork stoppers (450410) have been identified. Thus, the trade-off flows have been simplified into four groups from the four digit codes, which are 4501, 4502,4503 and 4504 , because no relevant information is specified within the six-digit subgroup. These groups are reflected in the study as raw cork, half-manufactured cork, natural cork stoppers and agglomerated cork products, respectively.

Table 2: HS classification for cork and its manufactures. (UN, 2010)

\begin{tabular}{|c|c|c|c|c|}
\hline \multirow{7}{*}{ 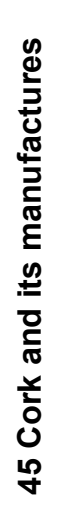 } & \multirow{2}{*}{4501} & \multirow{2}{*}{$\begin{array}{l}\text { Raw cork, raw or simply } \\
\text { prepared; waste cork, crushed, } \\
\text { granulated or ground cork. }\end{array}$} & 450110 & Natural cork, raw or simply prepared. \\
\hline & & & 450190 & Others. \\
\hline & 4502 & \multicolumn{3}{|c|}{$\begin{array}{l}\text { Natural cork, debacked or roughly squared, or in rectangular (including square) blocks, } \\
\text { plates, sheets or strip (including sharp-edged blanks for corks or stoppers). }\end{array}$} \\
\hline & \multirow{2}{*}{4503} & \multirow{2}{*}{ Articles of natural cork } & 450310 & Cork stoppers \\
\hline & & & 450390 & Others \\
\hline & \multirow[t]{2}{*}{4504} & \multirow{2}{*}{$\begin{array}{l}\text { Agglomerated cork (with or } \\
\text { without a binding substance) and } \\
\text { articles of agglomerated cork }\end{array}$} & 450410 & $\begin{array}{l}\text { Blocks, plates, sheets and strip, tiles of any } \\
\text { shape, solid cylinders, including disks. }\end{array}$ \\
\hline & & & 450490 & Others \\
\hline
\end{tabular}

To collect this data, national statistics on imports and exports in terms of mass (tonnes) and monetary (US\$) flows during 2012 have been obtained. The results for Portugal and Spain have been compiled by performing specific research on the trade-off countries by nation according to the United Nations Commodity Trade Statistics Database (UN Comtrade, 2013). In the case of Catalonia, these data are collected from an external trade database called the Base de Datos de Comercio Exterior (ESTACOM-EUROESTACOM, 2013). The results for Portugal and Spain are contrasted with the data provided by ESTACOM-EUROESTACOM (2013), EUROSTAT (2013), BACl (Gaulier and Zignago, 2010) and APCOR (2014) to ensure that there are no substantial differences. The Catalan results are contrasted with the trends of previous years because of an absence of different data sources.

It should be noted that the flows of cork products included in other finished products (e.g., the cork stoppers that are found in bottles of wine, champagne and cava) are not considered in the study. Stoppers of different types and materials are used according to the importing country and the quality of the wine or champagne. There is no reliable information available on these flows, and their inclusion could distort the outcome of the study.

\footnotetext{
${ }^{1}$ A tariff nomenclature for internationally standardized system of names and numbers to classify traded products as developed by the World Customs Organization (http://www.wcoomd.org/fi).
} 


\section{Results}

The results obtained from the trade study are detailed below. They have been calculated in terms of physical mass and in monetary quantities for each area, namely the lberian Peninsula, Portugal, Spain and Catalonia to obtain a general view of the differences within the market and the value of cork as a commercial product in the Iberian Peninsula.

\subsection{Global level: Iberian Peninsula}

Cork exploitation in the Iberian Peninsula is performed over 1,290,248 ha, producing 161,504 tonnes of cork, for an average of $120 \mathrm{Kg} / \mathrm{ha} /$ year (Figure 2). This rate can be higher or lower depending on different factors such as climate conditions, tree age, the density of exploitation, and others (Pereira and Tomé, 2004). At the present time, Portugal extracts approximately half of the world's cork production, and the cork produced by Spain represents over $30 \%$ of the total. These rates indicate that $80 \%$ of the cork extracted worldwide comes from the Iberian Peninsula (Table 1). The cork industry is a significant part of the Portuguese and Spanish economies, and it represents $1.5 \%$ and $0.9 \%$ of their industrial production, respectively (Autoridade da Concorrência 2012, INE 2013). Moreover, Portugal and Spain are global leaders in the cork sector, concentrating most of their cork trade flows with the rest of the world (Parejo 2009, Zapata 2009, Parejo 2004, Zapata 2002). Figure 2 shows economic indicator data for the cork sector from the Iberian Peninsula. It also shows a broad picture of the Iberian cork industry and the different cork regions in Portugal and Spain. 


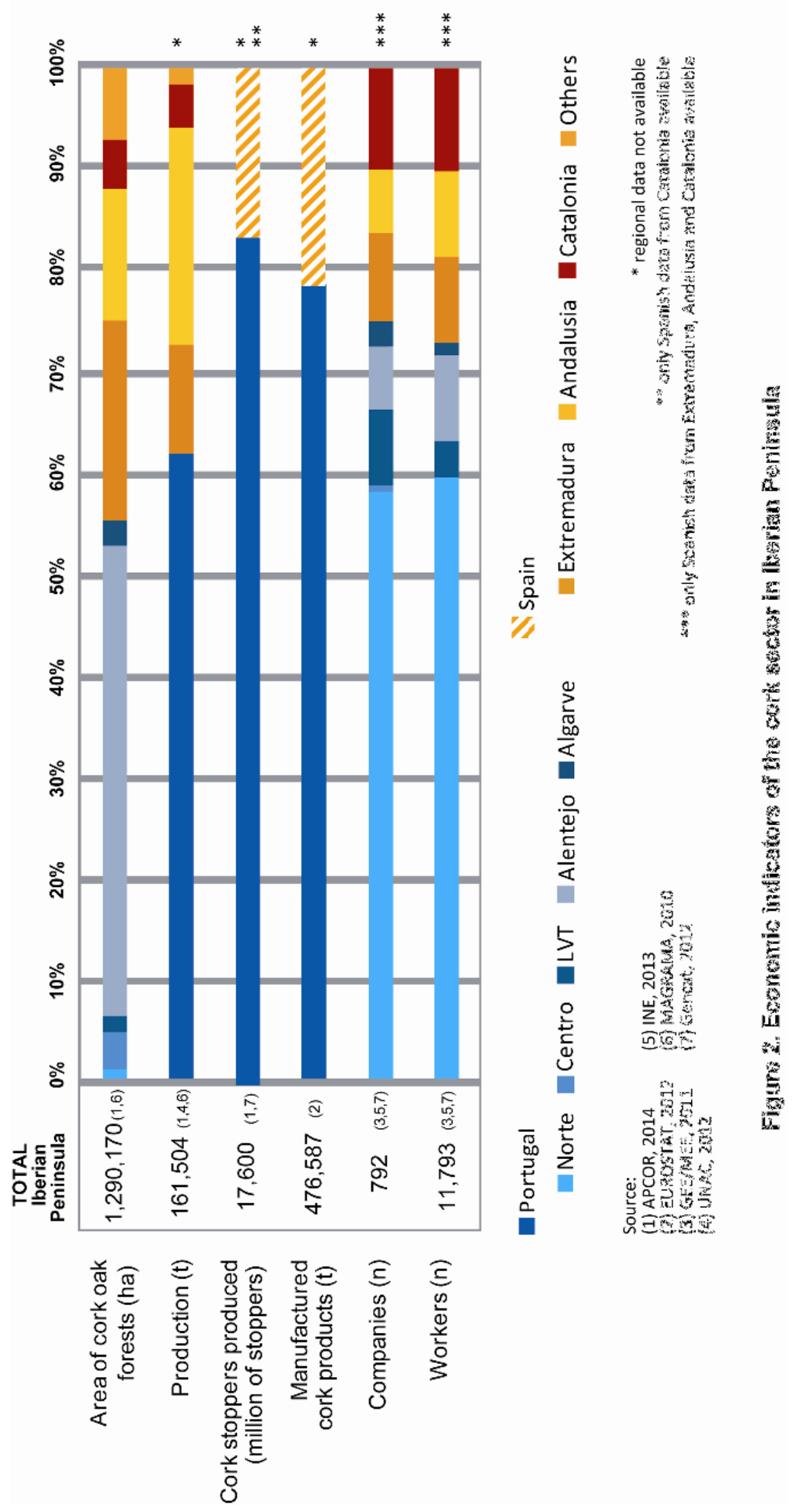


With regards to the global trade of the Iberian cork production sector, the Iberian Peninsula is the epicentre of the world cork market, as shown in Figure 3. This leadership indicates the importance of the Iberian Peninsula as an exporter to other continents, from which the flows of cork products have their origin primarily in the Iberian Peninsula. Moreover, Figure 3 shows the primary countries that import cork products from the Iberian Peninsula. One of the largest importers is Germany, and it primarily imports agglomerated cork as a building material. The high import data in mass and monetary quantities for France, the USA, and Italy are associated with their positions as global leaders in wine production and bottling. The high growth rates in Chile and Argentina should be noted (OIV, 2013). This growth explains why important flows of natural cork stoppers take place in these areas. The Iberian Peninsula hosts important sectors including producers and bottlers of wine and sparkling wine (champagne and cava); they export millions of bottles all over the world that contain natural cork stoppers or agglomerated cork stoppers. Spain is the third largest producer and the second largest exporter of wine; Catalonia is the second largest producer and the first largest exporter of sparkling wine (OIV, 2013). These sectors distribute millions of bottles around the world, and thus the actual flows of processed products from cork should be higher than the quantities included in this study.

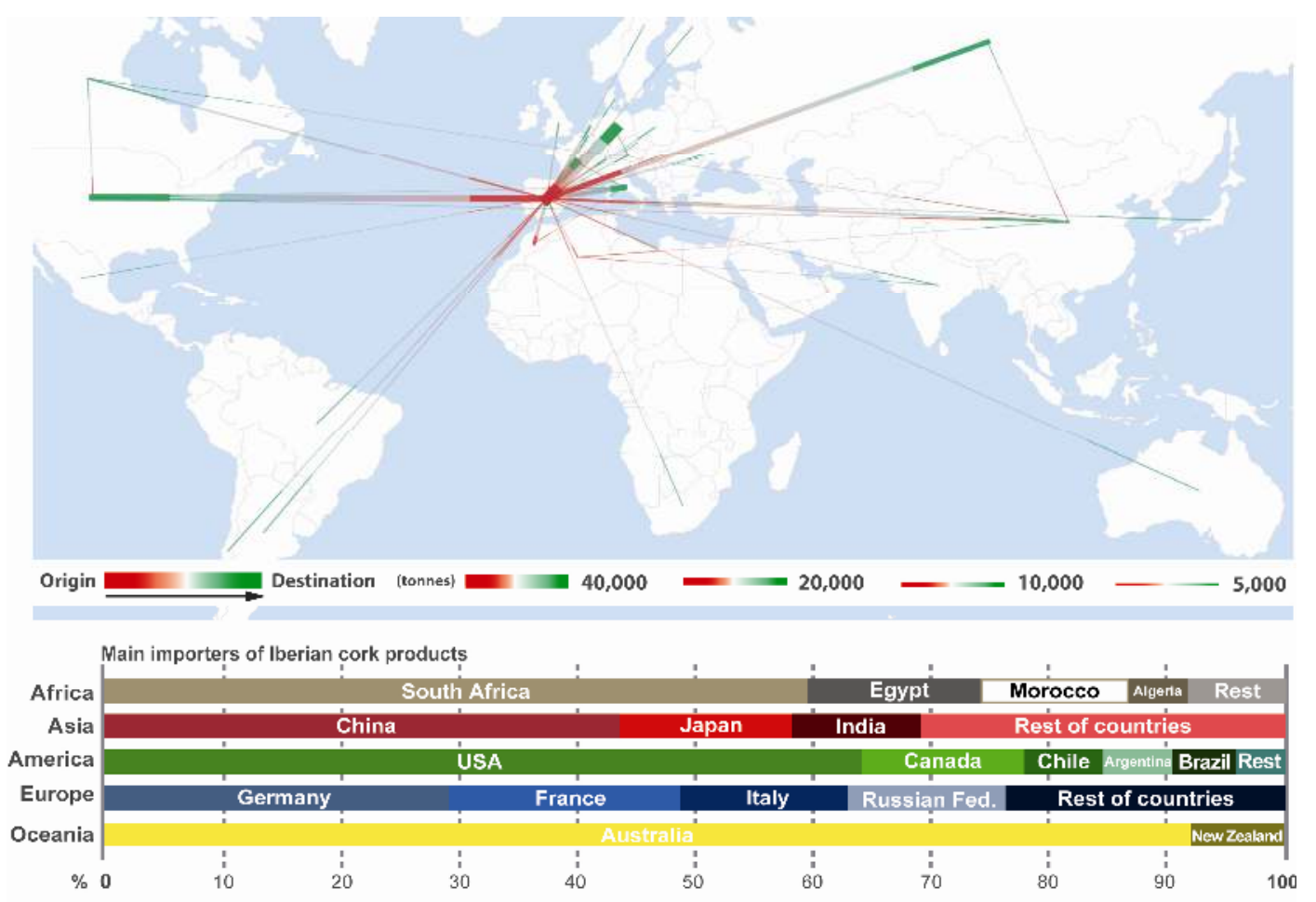

Figure 3. The global trade distribution of Iberian cork products (UN Comtrade 2013, Boyandin et al. 2010).

If the imports and exports data are broken down, it becomes clear that the mass quantity of imports in the Iberian Peninsula is 23,553.16 tonnes and US\$49 Million, and the export amounts are 174,050 tonnes and US $\$ 1,147.5$ Million, showing the high export capacity of the cork sector. In mass terms, the exports are 6 times higher than the imports, and in monetary terms, exports are 23 times higher than imports. In terms of physical mass, the most frequently imported product is raw material, but in monetary terms, natural cork stoppers are the most frequently imported products. For exports, agglomerated cork accounted for the majority of the exports in both mass and value; natural cork stoppers, despite representing a low mass quantity, play an important role in the value of exports. However, Figure 4 shows the percentage distributions of exports and imports in the Iberian Peninsula, as expressed for each individual continent by product type, which refers to the total amounts from a specific region. Over $60 \%$ of the import volume comes from North Africa, primarily as raw material, and the 
remaining imports are often from European countries. In the case of exports, the primary importers of cork products from the Iberian Peninsula are European countries, accounting for $50 \%$ of total exports; they are primarily Germany, France, Italy and the Russian Federation (Figure 3). The rest is part of the American trade flow, in which the USA imports $12 \%$ of the total exports (Figure 3).
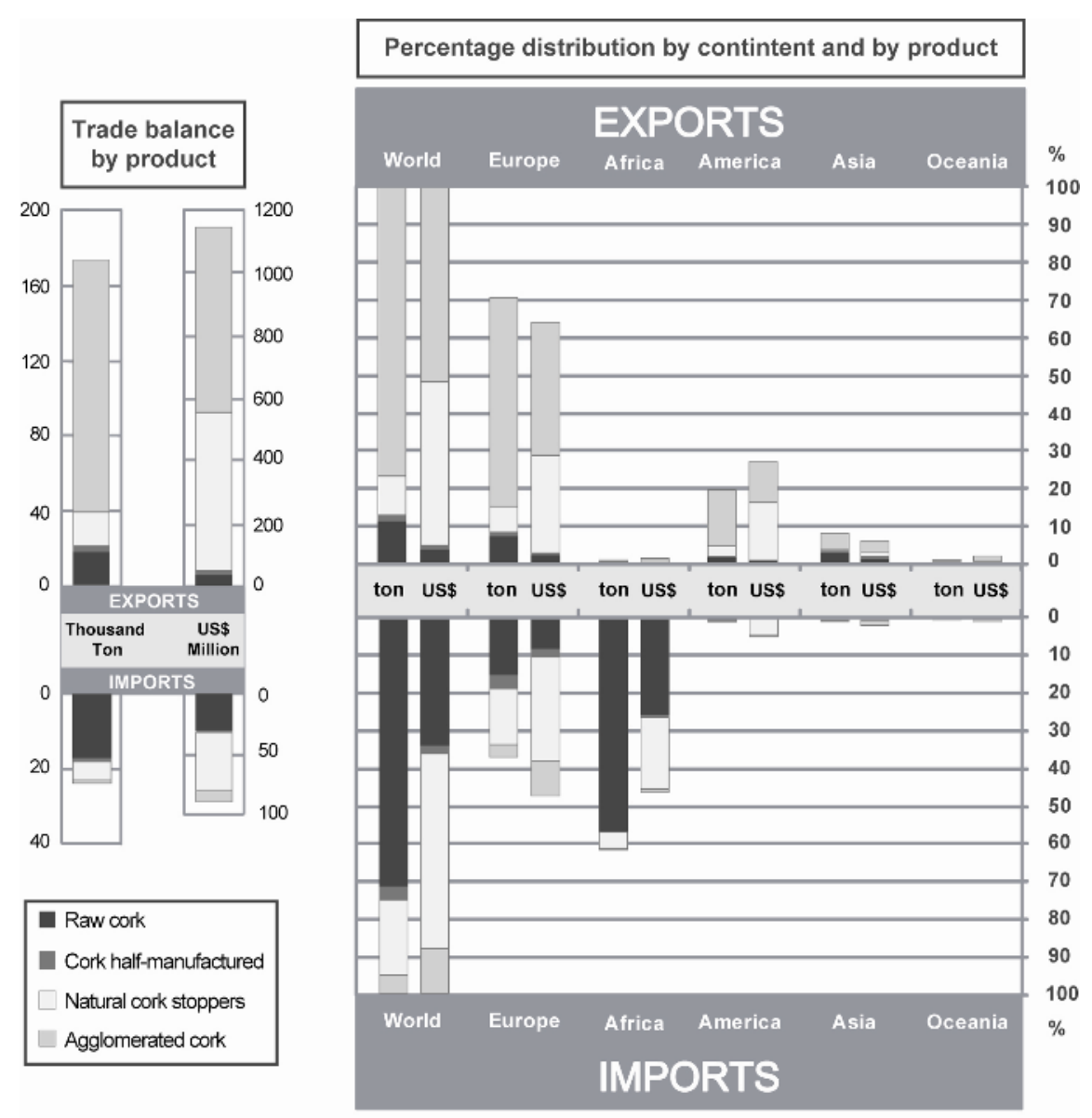

Figure 4. Trade of the Iberian Peninsula cork production (2012)

Source: UNComtrade, 2013

\subsection{Country level: Portugal and Spain}

Portugal produces a considerable amount of peninsular cork with a productivity of 140 $\mathrm{Kg} / \mathrm{ha} /$ year (Table 1). In addition to cork extraction, Portugal has an important industry, and it has businesses related to cork and its processes. It is estimated that upon arriving at the production process, this cork is distributed into 40\% stopper manufacturing, 30\% thin cork bark and $25 \%$ by-products (APCOR, 2014). Figure 2 shows a broad picture from the Portuguese cork sector, and it presents the current economic situation in the cork sector of Portugal. There are 592 companies operating in the cork sector, producing 40 million cork stoppers a day and employing approximately 8,593 workers. Cork products are obtained from both small and large companies that can engage in the production of one product, or they can diversify their production. Eighty-five percent of these companies employ less than 250 people, but cork production is nevertheless a very dynamic industry, based on its transformative activity (GPP, 2006).

In the international trade of Portugal (Figure 5), the mass quantity of exports, which is 189,568 tonnes, is double the imports, or 71,545 tonnes, (2.6 times). The monetary quantity of the 
exports is 7 times the imports, or US $\$ 1,087$ Million compared with US\$153 Million. In monetary terms, the most frequently imported product is raw cork, and finished-cork products are the most frequently exported products. Moreover, Figure 5 illustrates the percentage distribution of exports and imports by product and continent. For imports, raw cork accounts for almost all imports, mostly from Spain and the rest from North African countries. Imports of natural cork stoppers represent $16 \%$ in monetary terms of the total imports in spite of representing merely $2 \%$ of the physical mass. Portuguese exports are characterized by a high percentage of agglomerated products in both mass and monetary terms, which primarily include champagne stoppers and building material. Raw cork has significant relevance, and natural cork stoppers, despite representing a minimal portion of exports in terms of mass value, account for approximately half the total exports in value terms. When analysing the data by continent, cork products are mostly exported to Europe except in the case of the USA, which is the third-largest importer, especially for agglomerated cork. If the exports are compared with national production $(100,000$ tonnes), the extraction of Portuguese raw cork only covers half the national production needs. According to Zapata (2002), this gap explains the importance of raw material imports. From an economic approach, Portugal generates a significant increase in the value of its own forest resources. Moreover, it buys more raw materials from other countries at a low price. For that reason, the final balance between its sales and its own cork production is an increase of $25 \%$ in raw cork to process into other cork products with higher values. Portugal produces over 165,000 tonnes of finished products, which represents approximately US $\$ 1,300$ Million (EUROSTAT, 2012), of which US $\$ 566$ Million of agglomerated cork is exported (champagne stoppers and building material) and US $\$ 490$ Million of natural cork stoppers, resulting in an economic value 9 times higher than that of the initial raw cork. These data provide an idea of the sector's characteristics and the importance of foreign trade and the cork-processing industry. These data also show how this link in the supply chain is able to generate wealth, significantly increasing the value of the raw material. In summary, Portugal is primarily considered to be an importer of raw cork, processing it industrially and selling it abroad as final products, which accounts for between 80 and $90 \%$ of its total production (Autoridade da Concorrência 2012, EUROSTAT 2012). 


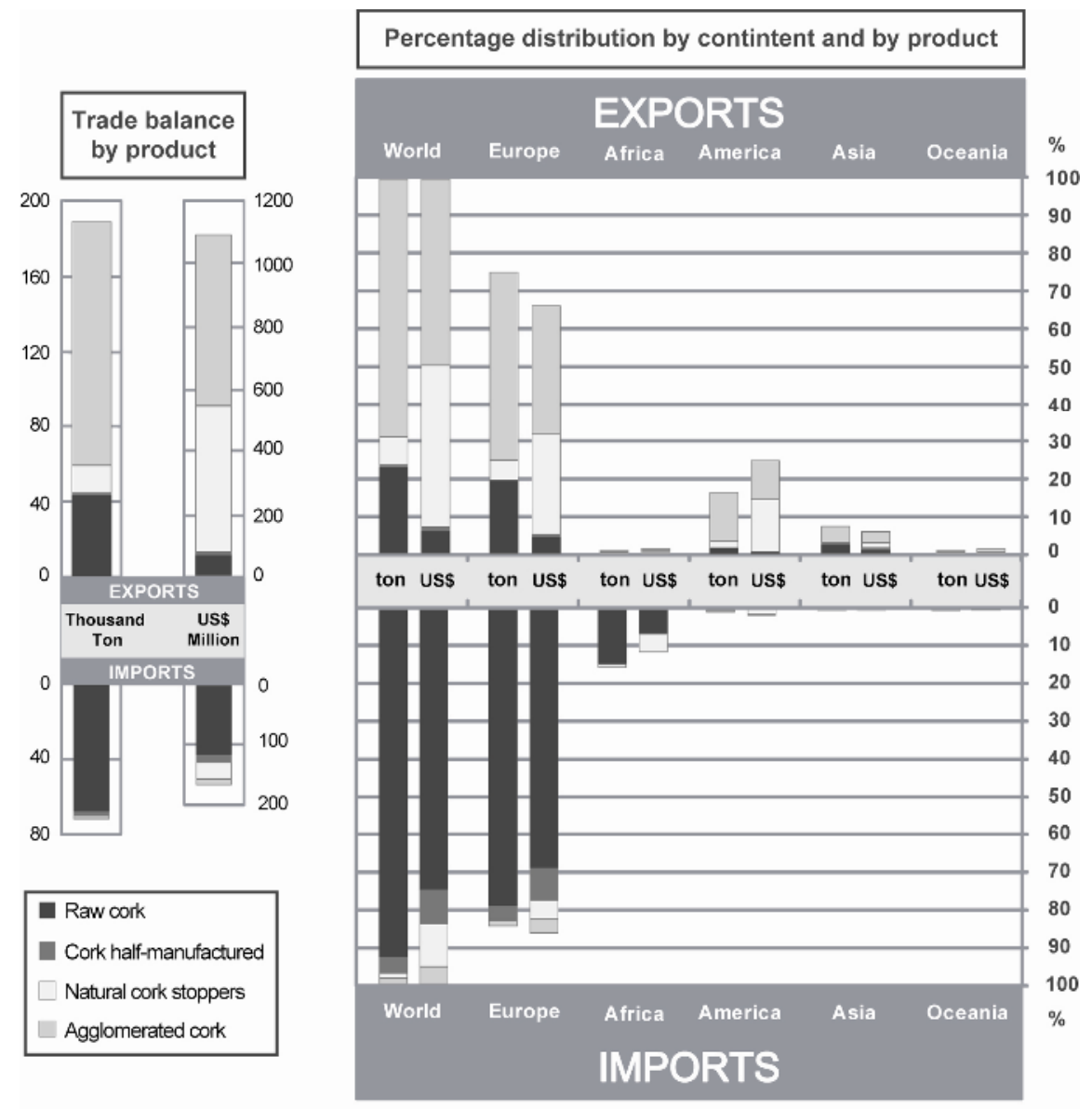

Figure 5. Trade of the Portugal cork production (2012)

Source: UNComtrade, 2013

As mentioned above, the Portuguese cork industry has developed significantly in the past century, in terms of sales and number of workers. Portugal has become a country that exports primarily manufactured products instead of raw cork, which is a change that occurred in the first half of the $20^{\text {th }}$ century (Zapata 2002). Portugal currently leads the world in Research and Development on cork, through various experiments, innovations and research projects that have been conducted since the early 1970s. These projects have been focused on identifying the opportunities associated with cork such as the environmental and eco-efficiency aspects of this material and the great potential of cork materials and technologies for new applications to diversify the current market (Mestre and Vogtlander 2013, Mestre and Gil 2011, Mestre 2008).

Spanish productivity, at $107 \mathrm{~kg} / \mathrm{ha} / \mathrm{year}$, is lower than that of Portugal (Table 1). Cork extraction is primarily concentrated in two southern areas, namely Andalusia and Extremadura. There is an area where cork is extracted in the North (Catalonia), and an important industry Cluster is also located there. A large portion of the cork extracted in Extremadura and Andalusia is transformed into final products in the North and also in Portugal. Figure 2 contains data collected from reference sources, and it is clear that Extremadura and Andalusia produced 19,032 and 37,882 tonnes annually, respectively. Additionally, small quantities of raw cork are extracted in other regions of Spain such as Castilla La Mancha and the Comunidad Valenciana, but in lower percentages. In Spain, the cork sector is composed of 200 companies and 3,200 workers. In southern Spain, the cork sector consists of 120 companies primarily based on the first stages of the supply chain, such as cork preparation, and it employs 2,000 workers. The cork sector of Catalonia will be discussed in the following section. 
Figure 6 shows that Spain exports more than it imports, with 1.4 times more mass volume and 2 times more in terms of monetary quantity. In terms of value, Spain imports and exports primarily natural cork stoppers but also exports agglomerated cork, which is primarily processed in Catalonia. The final balance between its own raw cork production and the raw material for processing is $10 \%$ less; and consequently, there is a lower final quantity in the processed products. Spain produces 20 tonnes of finished products, yielding US $\$ 253$ Million (EUROSTAT, 2012), and half of them are exported as agglomerated cork and natural cork stoppers. Nearly $25 \%$ of its production is for domestic demand, primarily by the wine sector. In the international trade of Spain (Figure 6), imports have some similarities with the Portuguese model such as imports from countries with cork oak forests. But there are also many countries from which already manufactured products are imported. The most frequently imported product in terms of physical mass is raw cork, but the percentage of already manufactured products is higher, with over $25 \%$ of natural cork stoppers and $10 \%$ of agglomerated cork. In all categories, Portugal is the primary supplier of processed cork products (natural cork stoppers and agglomerated cork), indicating a lower cork-processing ability in the Spanish industry. In analysing Spanish exports $(61,504$ tonnes), it becomes clear that raw exported cork represents $55 \%$ of Spanish cork production. Half-manufactured cork is the second-largest export in terms of physical mass and primarily comes from the southern regions of Spain. This type of product has a lower value, representing only $13 \%$ of total exports. In terms of countries, Spain exports primarily to Portugal, France and Italy, which import approximately $90 \%$ of total Spanish exports. Asian and American markets import more than $4 \%$.
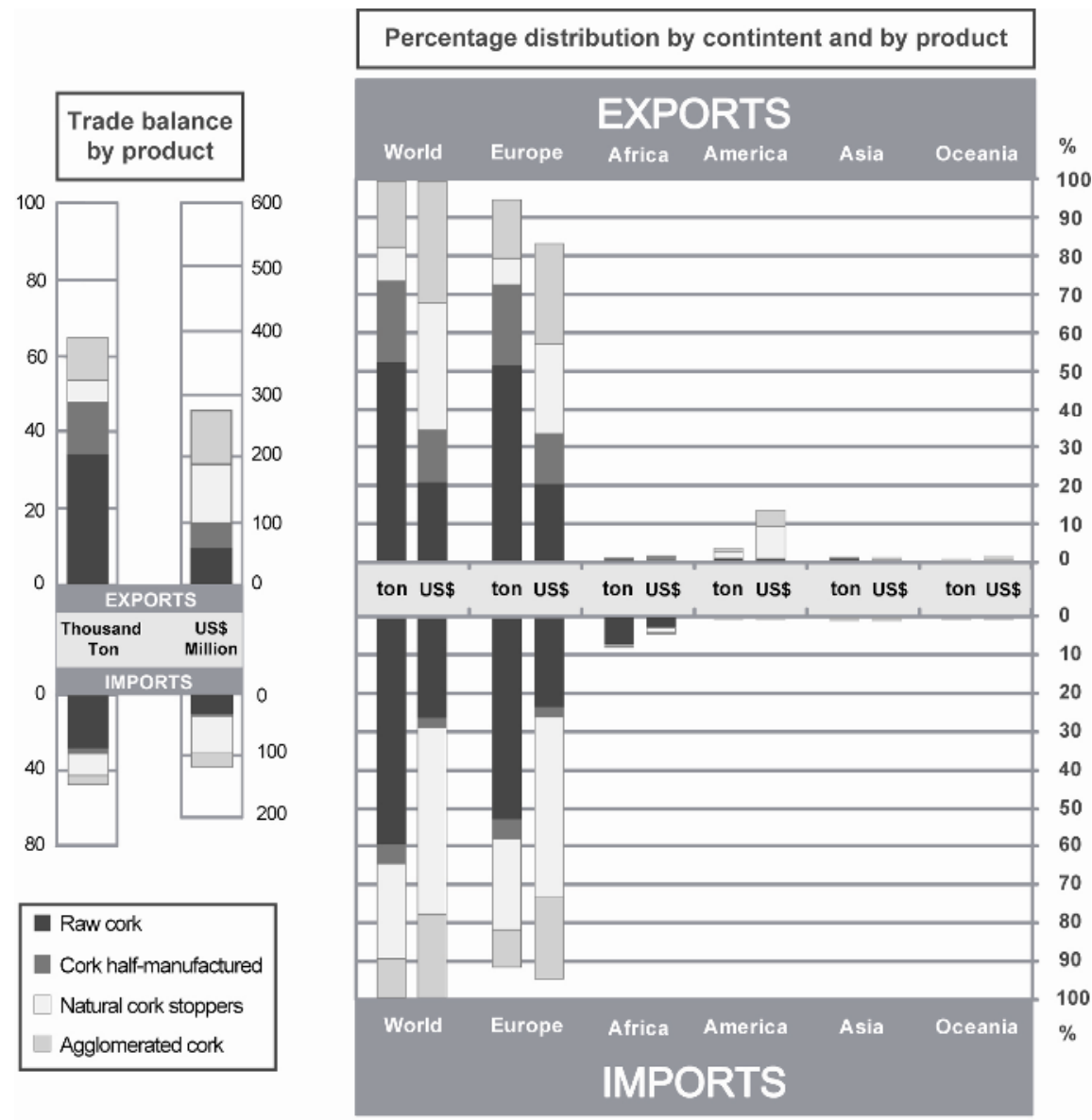

Figure 6. Trade of the Spain cork production (2012)

Source: UNComtrade, 2013 
These data reinforce the idea that the Spanish cork industry is currently based on raw material and half-manufactured cork as already indicated by Parejo and Zapata (Parejo 2010, Zapata et al. 2009). In contrast to Portugal, Spain has become a country that divides its exports between unmanufactured cork and manufactured cork products, instead of exporting only manufactured cork as it did in the first half of the $20^{\text {th }}$ century. Moreover, the Spanish imports have grown from negligible to nearly half of all exports, and they come primarily from Portugal, which represents a serious deterioration in the foreign trade of the Spanish cork industry (Zapata et al. 2009, Zapata 2002). According to this analysis, the economic potential of the cork oak forests as a natural resource is not fully used. Extensive resources have been invested in forestry labour and cork extraction, but not all the extracted raw material passes across the cork supply chain, and the possible added value is not maximized. With the exception of the Catalan case, which will be explained below, R\&D policies in Spain have not been promoted in the cork industry, for either the public or private sectors. This is true despite the fact that it is a country with a high level of innovation in various productive sectors and, more specifically, in eco-innovation (EIO, 2013).

\subsection{Regional level: Catalonia}

At the regional level, Catalonia differs from the rest of Spain because of the different production and industrial models in its cork sector. This distinction may indicate significant differences in the data. In reference to Figure 2, the Catalan cork sector hosts 63,000 ha of cork oak, and its industry is based on 80 companies. It produces 7,600 tonnes of raw cork and 3,000 Million cork stoppers per year.

In the international trade of Catalonia (Figure 7), the mass quantity of exports is 1.5 times higher than the imports. In terms of monetary quantity, its exports are 3 times the imports. In mass quantity, the most frequently imported product is raw cork, and in monetary terms, natural cork stoppers are the most frequently imported products. Agglomerated cork is the most frequently exported product both in mass and monetary terms. This trend fits precisely with Rives et al. (2012a), who wrote that Catalonia is the largest producer of agglomerated corks and especially of champagne and sparkling wines with $60 \%$ of global production. The Catalan cork sector has a turnover of US $\$ 1,160$ Million $^{2}$ (INE, 2013), of which $20 \%$ occurs abroad, US $\$ 50$ Million is from natural cork stoppers and approximately US $\$ 100$ Million is from agglomerated cork. In foreign trade, exports of natural cork stoppers and champagne stoppers provide 4 times more income than the expenses of imported raw cork. Catalonia imports raw cork primarily from European countries, namely Portugal, Italy and France. Natural cork stoppers are representative of imports; although they represent over $16 \%$ of the total import mass, they make up $61 \%$ in monetary terms (Figure 7). These natural cork stoppers are imported from European countries, primarily Portugal and France. For exports, Figure 7 shows that the most frequently exported products are agglomerated cork products, and also, at a significantly lower percentage, raw cork. These data may reflect the better industrial capacity of its cork industry than that of Spain, with its broader-based material processing. In the cases of Catalonia and Portugal, the cork-toprocess balance increases the initial raw cork by $28 \%$ (7,600 t) because Catalonia imports more raw cork than it exports. Important differences can be drawn between Catalan and Spanish results. For example, $72 \%$ of Catalan cork production is exported to Italy, Portugal and France as agglomerated products, but this percentage in the Spanish case is approximately $10 \%$. In contrast, Catalonia must import raw cork because its raw cork production only represents $65 \%$ of its production, which is then transformed and exported as products, primarily as agglomerated cork. The influences of the champagne or cava market should be noted in the Catalan cork sector because of the huge quantity of agglomerated cork stoppers required for exports and for its own use.

\footnotetext{
${ }^{2}$ Considering all 162 sectors in the Spanish Classification of Economic Activities: Wood and Cork (excluding furniture).
} 

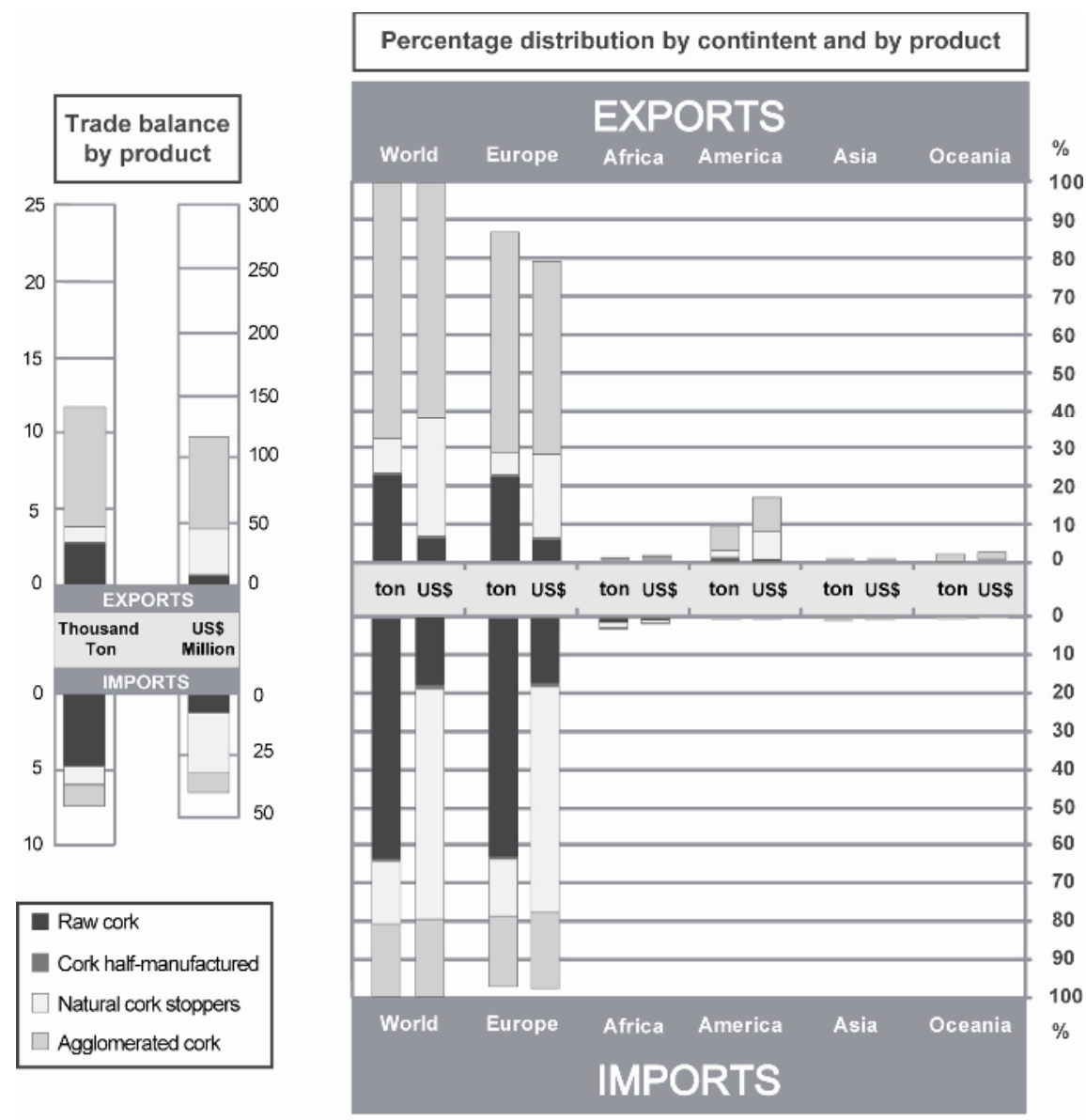

Figure 7. Trade of the Catalonia cork production (2012) Source: ESTACOM-EUROESTACOM, 2013

From an economic point of view, Catalonia focuses its cork industry on manufactured products, and so does Portugal, which generates an increase in the added value of the initial raw cork. Most of the raw cork is imported due to low cork production, and this dependence limits the development of its industry. Catalan cork oak forests are not fully used at present, and it is estimated that $50 \%$ of them are not managed in any way (Tusell and Garcia, 2008). If the exploitation of these forests begins, cork extraction in Catalonia could be doubled, and this dependence would decrease. According to Zapata (2002), the Catalan sector had the largest concentration of cork manufacturing industry worldwide in the early $20^{\text {th }}$ century, but in the first half of the $20^{\text {th }}$ century, setting the Spanish trend, there was a dramatic decline in the cork industry. This scenario currently gives more reasons to be optimistic; government agencies have identified the cork industry as a strategic sector, and the Catalan Cork Institute has been established to promote cork products or boost R\&D activity. Moreover, because of the geographic concentration of agents involved in the cork market, both in industry and forestry, a Cluster was created. Sustainability is one of the strategies that the Cluster wants to strengthen.

\section{Discussion}

It is difficult to obtain good quality statistical data on the production and external trade of cork products, and therefore different sources were consulted during data collection, namely UN Comtrade (UN, 2013), ESTACOM-EUROESTACOM (2012), EUROSTAT (2012) and BACI (Gaulier and Zignago, 2010). The data generally exhibit similar trends, although there are some fluctuations in one of the databases presented here. In Figure 8, the data for exports and 
imports from Portugal and Spain that were collected in each database are shown as an example.

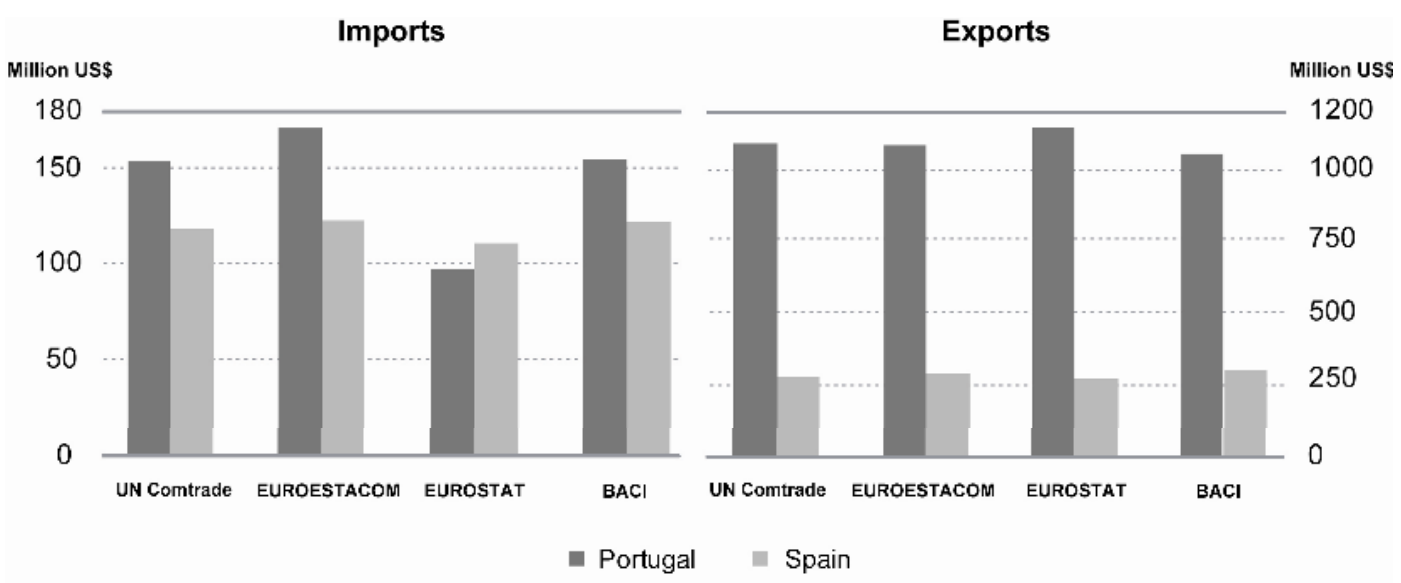

Figure 8. Comparison of different sources of information to trade data from Spain and Portugal (2012)

UN Comtrade is a global database generated from various sources from national authorities; they are standardized by the UN Statistics Division and then added to UN Comtrade (UN, 2009). Some of the databases employed here can be highlighted, such as EUROSTAT (Statistical Office of the European Communities), the U.S. Census Bureau, the IMF (International Financial Statistics) and private sources. The data starts with an estimate that is adjusted during the two years that follow and analysed through actual data provided by the national offices (UN, 2004). The BACl (Gaulier and Zignago, 2010) is a database that processes data from UN Comtrade to reconcile the information asymmetries that exist between countries. However, the reconciliation of exporter and importer reporting in $\mathrm{BACl}$ provides a significant improvement; it does not provide an assessment of the reliability of an entire database or of individual data points. The UN Comtrade database was ultimately used because it more closely represents the reality of the commodities market, and the rest of the databases are specialized in the external trade of a country. Moreover, this database has harmonized data about the cork trade because the primary cork-trading countries are developed countries, which use established standards for the exchange and diffusion of statistical trade data. BACl was discarded because the available data referred only to the 1994-2007 period, which is prior to the crisis in Portugal and Spain, and they could not represent the current situation.

In focusing on the empirical results of the cork industry trade, there are clear differences between the sectors within the Iberian Peninsula, following the trend that Parejo (2009) reported. On the one hand, Portugal and Catalonia primarily process raw cork into finished cork products; and on the other hand, the southern regions of Spain are eminent producers of raw cork. From an economic point of view, the industries focused in manufactured products are more capable of generating wealth because they greatly increase the value of the initial raw material. The southern regions of Spain are not capable of fully using the potential that cork, as a natural resource, provides. However, this potential is transferred to Portugal and Catalonia at a low price, which increases the initial value 9 and 4 times, respectively. In Table 3 , the ratio of the value (US\$) per mass unit $(\mathrm{Kg})$ can be compared for each flow and by product type. This ratio allows us to identify the major and minor valuable flows, and to compare the business characteristics of each type of flow. It can be used to identify more specifically the significant differences between the three analysed sectors. Catalonia has the largest ratio of total exports and imports, and its cork sector would have the greatest capacity to generate wealth. However, because the trade of Catalonia is still lower than that of Portugal and Spain and its market is focused on cork stoppers for champagne, the cork industry has not yet reached the degree of desired competitiveness. In the case of Portugal, its capacity to generate wealth is high because its exports are focused on the finished products with high added value, especially in 
relation to natural cork stoppers. Although agglomerated cork accounts for the majority of physical exports, it still represent a low percentage in terms of monetary value, with great potential for innovation in new products with high added value. Thus, this industry can be developed through its productive structure because of its large number of enterprises and the huge number of workers. Spanish data, including Catalan data, has the lowest rate for total exports. If Catalan data are not taken into account, the ratio for Spanish exports for natural cork stoppers and agglomerated cork is reduced by one-third, indicating the lower capacity of the rest of Spain to generate wealth.

Table 3: Ratio of the value (\$) per unit volume (Kg) for trade flows (2012), (UN Comtrade, 2013).

\begin{tabular}{|c|c|c|c|c|c|c|c|c|c|}
\cline { 2 - 9 } & \multicolumn{4}{c|}{ Country level } & \multicolumn{2}{c|}{$\begin{array}{c}\text { Regional } \\
\text { level }\end{array}$} & \multicolumn{2}{c|}{} \\
\cline { 2 - 10 } & \multicolumn{3}{|c|}{ Portugal } & \multicolumn{2}{c|}{ Spain } & \multicolumn{2}{c|}{ Catalonia } & \multicolumn{2}{c|}{ Rest of Spain } \\
\cline { 2 - 10 } & $\begin{array}{c}\text { Import } \\
(\$ / \mathrm{Kg})\end{array}$ & $\begin{array}{c}\text { Export } \\
(\$ / \mathrm{Kg})\end{array}$ & $\begin{array}{c}\text { Import } \\
(\$ / \mathrm{Kg})\end{array}$ & $\begin{array}{c}\text { Export } \\
(\$ / \mathrm{Kg})\end{array}$ & $\begin{array}{l}\text { Import } \\
(\$ / \mathrm{Kg})\end{array}$ & $\begin{array}{c}\text { Export } \\
(\$ / \mathrm{Kg})\end{array}$ & $\begin{array}{c}\text { Import } \\
(\$ / \mathrm{Kg})\end{array}$ & $\begin{array}{c}\text { Export } \\
(\$ / \mathrm{Kg})\end{array}$ \\
\hline TOTAL & 2.3 & 5.7 & 2.5 & 4.2 & 5.4 & 10.4 & 1.9 & 2.8 \\
\hline Raw cork & 1.7 & 1.4 & 1.1 & 1.6 & 1.4 & 2.6 & 1 & 1.5 \\
\hline Cork half-manufactured & 4.9 & 7.0 & 1.2 & 2.6 & 11.4 & 18.5 & 1 & 2.6 \\
\hline Natural cork stoppers & 19.3 & 32.5 & 5.0 & 15.5 & 20.1 & 35.3 & 3.2 & 11.1 \\
\hline Agglomerated cork & 6.4 & 4.1 & 5.2 & 7.7 & 5.7 & 9.6 & 5 & 3.1 \\
\hline
\end{tabular}

The crucial role of finished cork products is confirmed in the lberian cork industry because of their capacity to generate wealth. This wealth is not only generated by the economic value added to the raw material during the manufacturing process, but it also generates the development of different links in the supply chain, stimulating the establishment of companies that process the raw material that is currently exported from Spain. Wealth is not only obtained from large areas of cork oak from which to extract the raw material but also through an industrial structure that integrates each link of the cork supply chain. This integration could take advantage of its own natural resources, producing manufactured products with high values that will enhance its competitiveness. This direction could involve the development of rural areas where cork is the primary economic activity, and it would generate employment. In short, all this activity would be especially relevant in countries where the cork business network has been reduced dramatically and the unemployment rate is above $20 \%$, as in Spain. In this respect, the European Union has an active rural development policy to achieve valuable goals for the countryside and for the people who live and work there. With over $56 \%$ of the population in the European Union (EU) living in rural areas, rural development is a vitally important policy area. In particular, as in the past, this policy will be implemented through national and/or regional rural development programmes (RDPs) over the 2014-2020 period (EU, 2013). In line with Europe 2020 and the overall Common Agricultural Policy, three long-term strategic objectives can be identified for EU rural development policy in the 2014-2020 period, namely improving the competitiveness of agriculture, the sustainable management of natural resources and climate action, and the balanced territorial development of rural areas. These objectives clearly reinforce the idea of strengthening each link of the supply chain in the cork industry and making them part of the same structure to achieve common goals.

Moreover, the cork-manufacturing industry can play a decisive role in the promotion of raw cork as a renewable source for a finished cork product with high added value, in addition to the use of finished cork products as a by-product of some other type of product. These new products could expand the cork market to other sectors because it is currently too focused on the wine market and depends strongly on market trends. The wine market is concentrated in countries that produce, bottle and consume wine, which are mostly European, in addition to the USA, Argentina and Australia. Some potential applications are building material, transport, furniture, 
lighting or design; and as noted above, there is a great potential for innovation in new products made of agglomerated cork, and in taking advantage of other cork by-products and waste by transforming it into products with high added value. In Portugal, there are current cork applications in floor and wall coverings and insulation, among others, which represents a quarter of the value of its exports. Therefore, these applications currently make up a significant share of the market, but they can be increased by obtaining improvements in certain properties to better their performance in building systems. Moreover, the sustainability of this material is in line with strategic plans to reduce environmental impacts and energy consumption in the building sector (EU, 2010). This diversification would increase the competitiveness of the sector, and it may cause an increased demand for higher finished products and lead to greater economic wealth. In this way, e.g., Spain can decrease its raw material exports and increase its exports of cork-transformed products, resulting in an increase in export values. In addition, this activity would contribute to greater internal trade and half-manufactured cork and raw cork imports to meet demand within the internal market. In addition to the diversification of the cork market, other R\&D and innovation long-term strategies for this sector have to be established, which would account for the characteristics of renewable and non-infinite resources and its slow growth. On the one hand, these strategies should be focused on ensuring cork quality and that the required quantity is capable of responding to market demands. This result can be achieved through appropriate forestry activities, both public and private, which would ensure good natural regeneration in the cork oak forests. On the other hand, this R\&D should strengthen the sustainability and eco-efficiency in every link of the cork supply chain, not only as an inherent attribute from cork material. The environmental aspects should be integrated into the cork extraction, the manufacturing process, transport and distribution, use or disposal; it should become a hallmark of the cork sector. From an environmental point of view, the integration between forestry and the cork-processing industry could reduce the distances travelled to transport reproduction cork and consume local raw materials, and thereby reduce the related environmental impact. In previous studies, the importance of transport in the environmental balance has already been indicated, especially in raw material trade (Rives, 2011). The global cork industry trade has a high concentration of trade flows within the Iberian Peninsula and, consequently, those exported products require higher energetic needs to reach their destinations. These energetic needs significantly increase the environmental impact, which would alter the balance of $\mathrm{CO}_{2}$ emissions calculated in previous studies by means of LCA methodology (Dias et al. 2014, González-García et al. 2013, Rives et al. 2013a, 2012a, 2012b, 2012c, 2011). In future studies, previous environmental evaluations will be updated and assessed to quantify how the global market affects the overall impact of the product.

\section{Conclusions}

This paper has presented an analysis of the international cork trade sector in the Iberian Peninsula, which hosts most of the world's cork oak forests and cork processing industries. Its performance has followed the same trend as indicated in previous studies, consolidating its hegemony despite the economic crisis that Iberian countries have suffered. Portugal is a producer and a processor of raw cork, acting as a leader in the global market and acting as a very powerful industry. The Spanish cork industry is based on raw material and halfmanufactured cork. Catalonia is an exception because it is the global leader in the champagne stopper market. The primary weakness identified for all sectors is the excessive concentration of the cork sector in the wine market. Therefore, there is a potential opportunity for improvement through the diversification of cork products. The cork-manufacturing industry can play a crucial role in Iberian cork development. This industry can generate the development of different links in the supply chain, stimulating intermediate links and increasing the capacity of cork industry to generate wealth. This wealth is not only generated by the economic value added to the raw material during the manufacturing process, but it also involves the development of rural areas where cork is the primary economic activity, stimulating the establishment of companies that process the raw materials and providing employment opportunities. 
In the cases of Spain and Catalonia, forest management must be improved because of the lack of forest management in Spain. In the case of Catalonia, $50 \%$ of Catalan cork oak forests are not managed in any way. Improving the forest management would increase the quantity and the quality of the extracted cork. The increased cork quality will improve the performance of the cork-manufacturing products, and the availability of higher quantity raw materials will ensure a supply for the cork-manufacturing industry.

The cork sector in the Iberian Peninsula has to establish its own development strategies for the future. It has to increase investment in R\&D and innovation for long-term strategies, taking into account the characteristics of renewable and non-infinite resources and its slow growth. In addition to developing new products with higher added value, these strategies should strengthen the sustainability and eco-efficiency in every link of the supply chain, and not only as an inherent attribute of cork material. The environmental aspects should be integrated into cork extraction, the manufacturing process, transport and distribution, use or disposal; they should become a hallmark of the cork sector. 


\section{References}

APCOR. Anuario 2014, realcork.org

Aronson J, Pereira JS, Pausas JG (eds). Cork Oak Woodlands on the Edge: conservation, adaptive management, and restoration. Island Press. 2009.

Autoridade da Concorrência. Relatório Final. Análise do sector e da fileira da cortiça em Portugal. 2012.

Bojnec Š, Fertő I. Forestry industry trade by degree of wood processing in the enlarged European Union countries. Forest Policy Econ 2014; 40: 31-39.

Borges J, Oliveira ÂC, Costa MA. A quantitative approach to cork oak forest management. Forest Ecol Manag 1997; 97(3): 223-229.

Boyandin I, Bertini E, Lalanne D. In Using flow maps to explore migrations over time. In: Proceedings of Geospatial Visual Analytics Workshop in conjunction with The 13th AGILE International Conference on Geographic Information Science (GeoVA); 2010.

Campos P, Daly-Hassen H, Oviedo JL, Ovando P, Chebil A. Accounting for single and aggregated forest incomes: Application to public cork oak forests in Jerez (Spain) and Iteimia (Tunisia). Ecol Econ 2008a; 65(1): 76-86.

Campos P, Ovando P, Montero G. Does private income support sustainable agroforestry in Spanish dehesa?. Land Use Policy 2008b; 25(4): 510-522.

Christopher M. Logistics and Supply Chain Management: Strategies for Reducing Cost and Improving Service Financial Times: Pitman Publishing. London, 1998; ISBN 0273 630490: pp. 294.

Costa A, Oliveira AC, Vidas F, Borges JG. An approach to cork oak forest management planning: a case study in southwestern Portugal. Eur J For Res 2010; 129(2): 233-241.

Dias AC, Boschmonart-Rives J, González-García S, Demertzi M, Gabarrell X, Arroja L. Analysis of raw cork production in Portugal and Catalonia using life cycle assessment. The International Journal of Life Cycle Assessment 2014; 19(12): 1985-2000.

EIO, Eco-Innovation Observatory. Eco-innovation in Spain; 2013, (http://www.ecoinnovation.eu/images/stories/Reports/EIO Country Brief 2013 Spain.pdf ) (accessed June 2014)

ESTACOM-EUROESTACOM, Base de Datos de Comercio Exterior; 2012, (http://www.icex.es/) (accessed December 2013).

EUFORGEN, Distribution map of cork oak (Quercus suber ) 2009, www.euforgen.org

European Union (EU). European Charter for Rural Areas. Committee on Agriculture and Rural Development, Council of Europe 1996.

European Union (EU). Council Decision 2006/144/EC of 20 February 2006 on Community strategic guidelines for rural development (programming period 2007 to 2013) 2006.

European Union (EU). Energy Performance of Buildings Directive 2010/31/EU (EPBD), Brusels, 2010. 
European Union (EU). Regulation (EU) No 1305/2013 of the European Parliament and the Council support for rural development by the European Agricultural Fund for Rural Development (EAFRD) and repealing Council Regulation (EC) No 1698/2005, 2013.

EUROSTAT. Statistics on the production of manufactured goods Value ANNUAL 2012. (http://epp.eurostat.ec.europa.eu/) (accessed February 2014).

Garrett HG, Buck L. Agroforestry practice and policy in the United States of America. Forest Ecology and Management 1997; 91(1): 5-15.

Gaulier G, Zignago S. BACI: International trade database at the product-level. The 1994-2007 version. Published in: CEPII Working Paper No. 2010-23, 2010.

GEE/MEE. Gabinete de Estratégia e Estudos, Ministério da Economia e do Emprego. Governo de Portugal, Quadros de Pessoal, ISBN: 978-989-98252-3-9, 2011.

Gencat. Generalitat de Catalunya. Informe annual sobre la industria en Catalunya, 2012

González-García S, Dias AC, Arroja L. Life-cycle assessment of typical Portuguese cork oak woodlands. Sci Total Environ 2013; 452: 355-364.

GPP. Gabinete de Planeamento e Políticas. Anuário Vegetal. Portugal 2006.

INE. Instituto Nacional de Estadística. Encuesta Industrial de Empresas. Spain 2013.

MAGRAMA. Ministerio de Agricultura, Alimentación y Medio Ambiente, Anuario estadística forestal. (Mapa Forestal de España (MFE), base cartográfica del Inventario Forestal Nacional (IFN)) 2010.

Megía T, Martín D. Observatori de prospectiva industrial. El clúster català del suro. Generalitat de Catalunya 2009.

Mestre A. Design Cork: For Future, Innovation and Sustainability. Lisboa: Susdesign 2008.

Mestre A, Gil L. Cork for sustainable product design. Ciència \& Tecnología dos Materiais 2011; 23: $n^{\circ} 3 / 4$.

Mestre A, Vogtlander J. Eco-efficient value creation of cork products: an LCA-based method for design intervention. J Clean Prod 2013; 57: 101-114.

OIV. International Organisation of Vine and Wine. Statistical report on world vitiviniculture, 2013.

Parejo Moruno FM. Siglo y medio de comercio exterior de productos corcheros en España; 0402: 1849-1999. Asociación Española de Historia Económica 2004.

Parejo Moruno FM. El negocio de exportación corchera en España y Portugal durante el siglo XX: cambios e intervención pública. Badajoz, Universidad de Extremadura 2009.

Parejo FM. El negocio del Corcho en España durante el siglo XX. Estudios de historia económica 2010; 57: 5-127, Madrid: Banco de España.

Pereira H, Tomé M. Cork oak and cork. In: Burley J. Evans J, Youngquist JA (Eds). Encyclopedia of For Sci. Elsevier, Oxford. 2004. p. 613-620.

Pereira H. Cork: biology, production and uses. Elsevier 2007. 336 pp 
Rives J, Fernandez-Rodriguez I, Rieradevall J, Gabarrell X. Environmental analysis of the production of natural cork stoppers in Southern Europe (Catalonia - Spain). J Clean Prod 2011; 30: 949-57.

Rives J, Fernandez-Rodriguez I, Rieradevall J, Gabarrell X. Environmental analysis of the production of champagne cork stoppers. J Clean Prod 2012a; 25: 1-13.

Rives J, Fernandez-Rodriguez I, Gabarrell X, Rieradevall J. Environmental analysis of cork granulate production in Catalonia - Northern Spain. Resour Conserv Recycl 2012b; 58: $132-42$.

Rives J, Fernández-Rodríguez I, Rieradevall J, Gabarell X. Environmental analysis of raw cork extraction in cork oak forests in southern Europe (Catalonia - Spain). J Environ Manag 2012c; 110: 236-45.

Rives J, Fernandez-Rodriguez I, Rieradevall J, \& Gabarrell X. Integrated environmental analysis of the main cork products in southern Europe (Catalonia-Spain). J Clean Prod 2013a; 51: 289-298.

Rives J, Gasol CM, Sánchez S, Boada M, Garola A. The value of ecosystem services of cork oak forests in Catalonia (El valor dels serveis ambientals de la suredes de Catalunya). ICSuro 2013b.

Tusell JM, Garcia RM. Gestió de la sureda: manual didàctic. Consorci Forestal de Catalunya, Santa Coloma de Farners , 2008, 51 pp.

UNAC. União da Floresta Mediterránica. Boletim de Mercado da Cortiça - campanha 2012, 2012.

United Nations (UN). International Merchandise Trade Statistics: Compiler's Manual 2004. (http://unstats.un.org/unsd/publication/SeriesF/seriesf_87e.pdf) (accessed January 2015).

United Nations (UN). Statistics division, Comtrade database, read me first, 2009. (http://comtrade.un.org/db/help/uReadMeFirst.aspx) (accessed January 2015).

United Nations (UN). Harmonized Commodity Description and Coding System (HS) 2010, (http://unstats.un.org/unsd/tradekb/Knowledgebase/Harmonized-Commodity-Descriptionand-Coding-Systems-HS) (accessed December 2013).

UN Comtrade. United Nations Commodity Trade Statistics Database. United Nations Statistical Division 2013. (http://comtrade.un.org/) (accessed December 2013).

World Customs Organization. Protocol of Amendment to the International Convention on the Harmonized Commodity Description and Coding System. Brussels 1986, (http://www.wcoomd.org/fi) (accessed December 2013).

Zapata S. Del suro a la cortiça. El ascenso de Portugal a primera potencia corchera del mundo. Revista de historia industrial 2002; 22: 109-140.

Zapata S, Parejo FP, Branco A, Gutierrez M, Blanco J, Renaud P, Voth A. Manufacture and trade of cork products: an international perspective. Cork Oak Woodlands on the Edge. Island Press, Washington, USA; 2009. p. 189-200 